Галина Камлевич

Белорусский государственный педагогический университет

имени Максима Танка

Филологический факультет

Кафедра общего и русского языкознания

tel.: +375-17-327-78-10

e-mail: kamlevich@mail.ru

\title{
Лексические и синтаксические особенности идиостиля Евгения Замятина
}

Ключевые слова: идиостиль Е. Замятина, лексика и синтаксис художественного текста.

Стиль выдающихся мастеров слова - это «совокупность осмыслений многообразных возможностей языка в его художественной функции» [Будагов 1984, 252], что подтверждает и творчество Е. Замятина. Решение главных вопросов замятинского творчества - отношение искусства к новой социальной действительности начала XX века, определение места человека в стихии событий, осмысление личностного начала в истории - обусловливает специфику художественных произведений Е. Замятина, проявляющуюся как на лексическом, так и на синтаксическом уровнях.

Писатель синтезировал научное и художественное познание, включая в прозаический контекст элементы новейшей философии и естественной науки. В связи с этим творческая манера Е. Замятина характеризуется богатством лексического диапазона (от разговорной лексики до терминологии и научной символики), окказиональностью, особым антропонимическим пространством. Эмоциональное восприятие человеком окружающей действительности отражается в синтаксической полифонии, в использовании избыточных (парцелляция, сегмен- 
тация) и экономных (неполнота, эллипсис, усечение) конструкций экспрессивного синтаксиса, в синтезе сказовости, орнаментальности и элементов «рубленой» прозы, что реализуется в особом пунктуационном рисунке художественных произведений Е. Замятина.

Терминологическая лексика и научная символика представлены во многих произведениях писателя, но особенно ярко функционируют в структуре романа «Мы», так как эксплицируют идею произведения: вытеснение техническим прогрессом всего человеческого в людях актуализируется посредством замены общеупотребительных слов специальными лексемами. В романе «Мы» зафиксировано свыше 400 терминов (около 650 словоупотреблений). Преобладание технической и математической терминологии связано с тем, что Е. Замятин был инженером-профессионалом, строил корабли и увлекался математикой. Также это определено художественными задачами, так как репрезентирует сущность «машинной цивилизации» и особенности искусственного интеллекта героев-нумеров.

Функционирование терминов в прозе Е. Замятина обусловливается прямым назначением (для определения понятий), а также системой эстетической коммуникации. Часто термины используются в изобразительной функции, для выражения экспрессивности и образности. В этом случае употребление специальных слов, как правило, метафорическое, а термины входят в состав эксплицитно выраженного сравнения: На меня эта женщина действовала так же неприятно, как случайно затесавшийся в уравнение неразложимый иррачиональный член [Замятин 1989, 209]. Иногда к изобразительной функции добавляется оценочная. При этом происходит вполне определенное осмысление персонажа или явления, выражается отношение к описываемому: $\mathrm{Ha}$ лево - О, совсем другая, вся из окружностей, с детской складочкой на руке [Замятин 1989, 208].

При помощи терминов, сочетающихся с общеупотребительными лексемами, создаются стилистические эффекты, в частности контраст и оксюморон, выражающие сатирическую или пародийную направленность, иронию. Есть случаи, когда специальные понятия противопоставляются друг другу, усиливая контраст, который мог бы быть при использовании обычных слов. Так, оппозиция равенство четьлех углов - бином Ньютона основывается на антонимичности слов привычно - ново, просто - сложно и ярче раскрывает ее: Понимаете, квадрату меньше всего пришло бы в голову говорить о том, что у него все четьре угла равнь: он уже просто не видит - насколько это для него привьчно, ежедневно... Ну хоть бы розовые талонь 
и все с ними связанное: для меня это - равенство четьрех углов, но для вас это, может быть, почище, чем бином Ньютона [Замятин 1989, 216].

Используются термины и в символическом, обобщенном значении. Так, в математике таблииа умножения - это перечень помножаемых друг на друга чисел в пределах первого десятка, с произведением от каждой пары. В романе «Мы» это словосочетание выступает как символ высшей мудрости, абсолютной истины: Таблииа умножения мудрее, абсолютнее древнего Бога: она никогда - понимаете: никогда не ошибается [Замятин 1989, 244].

Различные структурно-семантические типы научных символов (семантически пустые, наполненные содержанием в конкретном случае употребления; однозначные и многозначные; узкоспециальные и обобщенные; самостоятельные и входящие в состав сложных наименований) несут эмоционально-экспрессивную нагрузку, расширяют текстовое пространство, отражая картину мира Е. Замятина, особенности мышления и психоэмоционального состояния героев-нумеров, сверхрациональность «машиноподобной» жизни. В романе «Мы» действующие лица выступают под определенными буквенно-цифровыми кодами: Д-503, О-90, I-330. Н. Струве отмечал, что «цифры в романе первостепенны», вплетаются непосредственно в художественную структуру произведения, неся символическое значение [Струве 1986, 164]. Посредством символов может даваться оценка и дополнительная характеристика героев или происходящих событий: И все-таки один - благодетель, другой - преступник, один со знаком +, другой со знаком -... [Замятин 1989, 252].

Бинарная оппозиция Бог - человек (одна из основных в философии Е. Замятина), а также модернистский неомифологизм определяют широкое употребление автором религиозной лексики, устойчивых выражений, принадлежащих христианской культуре. Религиозный аспект проявляется на уровне названия произведений («Бич божий», «Сподручница грешных», «Церковь божия», «Дьячок») и их философии, на уровне конкретных персонажей и отдельных лексем. В прозе Е. Замятина встречается много выражений, связанных с христианской культурой, подвергшихся художественной трансформации: проводник в иарствие небесное, верил в религию, предать на алтарь. Введение лексики религиозного культа помогает автору противопоставить философию рабства и философию свободы, реализовать замятинский принцип «человекобожия», подтверждая, что для писателя центром Вселенной является человек, его чувства и переживания. 
Одной из доминант идиостиля Е. Замятина, вербализующей авторское видение мира, является окказиональность, которая заключается в использовании потенциальных и индивидуально-авторских новообразований, в трансформации семантики слов, расширении их лексической и синтаксической сочетаемости. Писатель опирается на языковую традицию и в то же время использует окказиональные модели словообразования, создавая словообразовательные (благодель, трудящие), фонетические (фичеааоу), фразеологические (проливал жизнь, сделал из мухи совершеннейшее из божьи творений), лексические (марфизм, раз-в-тысячу-лет, исподлобный) и семантические (лохмаmый - ненастоящий, не такой, как всегда; ржаветь - болеть душой, переживать, терять почву под ногами) окказиональные единицы. Семантические окказионализмы, основанные на реализации потенциала имеющихся в языке единиц, преобладают над лексическими, которые большей частью представлены словами-композитами. Окказиональные новообразования используются в функции художественной номинации, источника и носителя экспрессивного заряда, экспликатора оценочных представлений автора, а также в качестве основы для создания определенных стилистических эффектов (преобладает оскюморон) и игры слов. В целом, употребление окказиональных единиц полифункционально и является элементом системы изобразительных средств Е. Замятина, отражая свойственный модернистской прозе приоритет стиля над содержанием.

Специфику замятинского идиостиля составляет и особое антропонимическое пространство. Создание антропонимов на основе метафоризации (Бледа, Урванка), смешение планов социальной отнесенности при номинации персонажей (чиновник Зюньзя, председатель Филимошка), использование национальной окраски антропонимов (Давид Моршинкер, Краггс), прецедентных имен (Адам, Маркс) помогает автору наиболее ярко представить необходимый образ, дать его дополнительную характеристику, создать у читателя адекватное отношение к персонажам и происходящим событиям, включить эмотивно-оценочный компонент, репрезентировать ассоциативный потенциал, сформировать символический план произведений. Некоторые известные антропонимы автор подвергает творческому преобразованию, в связи с чем онимы приобретают новый оттенок и читатель может припоминать известных людей, но не отождествлять их с персонажами произведений (Мак-Интош, Фич-Джеральд).

Для замятинского художественного антропонимикона специфичной является номинация персонажей посредством цифр, букв, терминов 
биологии (червь Rhopalocera), только апеллятивных элементов (новый факт в виде человека, без имени). Для идиостиля Е. Замятина характерны обширные номинативные цепочки, создающие систему антропонимических синонимов, что позволяет усилить или ослабить значительность происходящего, актуализировать психологическое состояние персонажей, выразить отношение к ним автора и других действующих лиц.

В рассказе «Мамай» номинация персонажа претерпевает изменения. Герой представлен читателю как Петр Петрович Мамай (социальное положение определяет использование трехчленной структуры имени). В домашней обстановке, когда героя кормит жена, - это Петенька. Присутствует и разновозрастная номинация персонажа, подчеркивающая инфантильность героя: десятилетний вихрастый мальчик - сорокалетний льсенький мальчик. С точки зрения социальной наряду с элементом гражданин Мамай есть вариант господин Мамай, что усиливает двойственность героя, его жизненную неопределенность, приспособленчество и зависимость от других. Встречаем модель земной человек, которой герой именуется «перед Буддой», что позволяет автору противопоставить персонажа одноименному историческому герою и Будде. Главным с точки зрения идеи произведения является сравнение Мамая 1917 года и Мамая 1300 какого-то года. В итоге разграничение имен по времени исчезает и бывший Петенька именуется онимом Мамай; «мамайское» победило, когда герой «пригвоздил врага» (мышь). Многочисленные случаи полионимии, создание системы антропонимических синонимов показывает различное отношение автора и действующих лиц к герою, отношение писателя к тем, кто находится рядом с именуемым, помогает представить изменение отдельной ситуации или жизни героя в целом. Имена собственные оказываются важным стилеобразующим элементом творческой системы писателя.

Для творчества Е. Замятина приоритетным является не простое изображение действительности и реальных событий, а эмоциональное восприятие и переживание их человеком, поэтому идиостиль писателя на синтаксическом уровне формируется, прежде всего, средствами выражения эмоций и экспрессии. Е. Замятин умело оперирует набором синтаксических конструкций, актуализирующих высказывание, привлекает различные комбинации подобных структур. В соответствии с тенденциями модернистской литературы начала XX века писатель использует экономные и избыточные конструкции экспрессивного синтаксиса, соизмеряя их с формой произведения и конкретной художественной задачей. Беллетристика Е. Замятина включает элементы ска- 
зовости, представляющей собой языковую традицию, и новаторский «рубленый» синтаксис, что делает прозу писателя «синтетической», позволяет говорить о синтаксической полифонии.

В прозе писателя широко распространены собственно-неполные и эллиптические предложения, что обусловлено, наряду с решением художественных задач, самим темпом жизни начала XX века. Указанные конструкции придают повествованию динамичность, эмоциональность; выступают в функции речевой экономии; актуализируют атрибутивные и обстоятельственные характеристики речи, а не действие; используются для оформления определенных конструкций, имитации разговорной речи и «потока сознания»; выполняют интонационно-ритмичес кую функцию; реализуют модернистский принцип алогизма, неоднозначности и дисгармонии. Преобладание среди эллиптических предложений конструкций с опущением глаголов речи и мысли подчеркивает диалогичность замятинского стиля. Отсутствие глагольного сказуемого и других членов предложения позволяет выразить различные оттенки чувств, эмоции героев, усилить эффект неожиданности, стремительность действия, апеллировать к древним запретам произносить определенные слова: И тогда я - захлебььваясь, путаясь - все, что было, что записано здесь [Замятин 1989, 343]; И сквозь стеклянную дверь: все в комнате рассыпано, перевернуто, скомкано [Замятин 1989, 338]. И это все время неотвязно, нелепо, мучительно напоминает мне о чем-то, о чем нельзя, о чем сейчас - не надо [Замятин 1989, 340].

Усеченные конструкции, в которых имплицитная информация обладает различной степенью определенности, аккумулируют читательскую фантазию, заостряют внимание на вербально не выраженных сведениях, являются средством динамической смены планов повествования, источником ослабления или усиления субъектно-модальных значений, показателем психологического состояния персонажей, воспроизводя эмоциональную речь и акцентируя внимание на внутренних переживаниях героев. В ряде случаев усеченные предложения характеризуют психологические состояния, которые нельзя выразить одной какой-то эмоцией, так как они включают в себя целый комплекс переживаний. Так, прерванные конструкции нужны Е. Замятину для того, чтобы показать влюбленность героя, связанную с ней ревность и крайнюю степень возбуждения, взволнованности персонажа: Если я тебя... ну вот как... ну не знаю как... понимаешь? [Замятин 1989, 433]; Я убью всякого, кто... Потому что вас - я вас - - [Замятин 1989, 238]. Насыщенность прозаического контекста неполными и усеченными кон- 
струкциями определяется мировоззрением писателя, который считал, что «читатель и зритель сумеет договорить картину, дорисовать слова - и им самим договоренное, дорисованное будет врезано в него неизмеримо ярче, прочнее, врастет в него органически» [Замятин 1999, 80].

Идиостиль Е. Замятина характеризуется нарушением синтаксической цельности и связей в высказывании, сверхинтонированностью повествования, что проявляется в парцеллированных и сегментированных конструкциях и соответствует языковым тенденциям начала XX века. Данного рода расчлененность смещает логические акценты, является актуализатором главной информации, передает внутренние переживания героев, усиливает иронический подтекст, создает впечатление непосредственного формирования мысли, ее развертывания, модифицируют синтаксические отношения, выполняя тем самым изобразительную, эмоционально-выделительную, экспрессивно-грамматическую функции и функцию имитации разговорности. Синтаксическая трансформация репрезентирует различные оттенки чувств персонажей, преломляет языковое сознание писателя, расширяет эмоционально-экспрессивное пространство произведений.

В прозе Е. Замятина элементом системы изобразительно-выразительных средств выступает и пунктуация, которая также несет экспрессивную нагрузку. Так, большое количество скобок позволяет создать несколько линий повествования, подчеркнуть синтагматическую несвязность скобочного и основного сообщений, а в романе «Мы»- еще и передать наличие двух полярных миров - человеческого и «машинного». Посредством скобок в прозаический контекст вводится элемент драматургии - ремарка, которая усиливает диалогичность замятинского идиостиля.

Многочисленные случаи постановки знаков препинания в соответствии с художественным видением автора, а не с правилами пунктуации, изменяют интонационное оформление высказывания, нарушая мелодику, интенсивность и темп речи, задерживая или ускоряя повествование, модифицируя отношения между компонентами высказывания, что детерминируется задачами смыслового и стилистического характера.

Творчество Е. Замятина - писателя, философа, публициста, литературного критика, соединившего в своих произведениях тенденции орнаментальной прозы и принципы неореализма 20-30-х годов XX века, - занимает особое положение в общем потоке литературы первой трети XX века. Идиостиль Е. Замятина детерминирован философско-эстетическими взглядами автора, связан с особенностями 
языка начала XX века, характеризуется синтезом литературных традиций и новаторских элементов, лексической и синтаксической полифонией, что вызывает особый интерес и определяет необходимость дальнейшего исследования творчества писателя.

\section{Литература}

Будагов Р.А., 1984, Писатели о языке и язык писателей, Москва.

Замятин Е.И., 1989, Мв:: Романы, повести, рассказы, сказки, Москва.

Замятин Е.И., 1999, Я боюсь: Литературная критика. Публицистика. Воспоминания, Москва.

Струве Н., 1986, Символика чисел в романе Замятина «Мыљ», "Вестник русского христианского движения" № 147, с. 164-169.

\section{LEXICAL AND SYNTACTICAL PECULIARITIES OF ZAMIATIN'S IDIOSTYLE}

S U M M A R Y

The object of research is the language of Zamiatin's prose. The subject of the investigation is the lexical and syntactical elements, which can be categorized as the characteristic features of the author's idiostyle.

At the lexical level the author allocates terminology, scientific symbolics, religious lexicon, occasional elements and characterization as the main lines by Zamiatin's idiostyle. At the syntactic level the author considers the incomplete and elliptic sentences and also truncated, parceled and the segmented designs. The author reveals functional loading of the specified lexical and syntactic elements.

In article the conclusion is drawn that Zamiatin's idiostyle is characterized by lexical and syntactic polyphony and is connected with philosophical views of the writer, and also with features of language of the beginning of the XX century. 